\title{
Article
}

\section{Heterotopic Ossification of the Vascular Pedicle after Maxillofacial Reconstructive Surgery Using Fibular Free Flap: Introducing New Classification and Retrospective Analysis}

\author{
Michael Knitschke*D, Kelly Siu, Christina Bäcker, Sameh Attia D, Hans-Peter Howaldt and Sebastian Böttger \\ Department of Oral and Maxillofacial Surgery, Justus-Liebig-University, Klinikstrasse 33, \\ 35392 Giessen, Germany; kelly.siu@dentist.med.uni-giessen.de (K.S.); \\ christina.baecker-2@dentist.med.uni-giessen.de (C.B.); Sameh.Attia@dentist.med.uni-giessen.de (S.A.); \\ HP.Howaldt@uniklinikum-giessen.de (H.-P.H.); Sebastian.Boettger@uniklinikum-giessen.de (S.B.) \\ * Correspondence: Michael.Knitschke@uniklinikum-giessen.de
}

check for updates

Citation: Knitschke, M.; Siu, K.; Bäcker, C.; Attia, S.; Howaldt, H.-P.; Böttger, S. Heterotopic Ossification of the Vascular Pedicle after

Maxillofacial Reconstructive Surgery Using Fibular Free Flap: Introducing New Classification and Retrospective Analysis. J. Clin. Med. 2021, 10, 109. https://doi.org/10.3390/jcm10010109

Received: 21 October 2020 Accepted: 27 December 2020 Published: 30 December 2020

Publisher's Note: MDPI stays neutral with regard to jurisdictional clai$\mathrm{ms}$ in published maps and institutional affiliations.

Copyright: (C) 2020 by the authors. Licensee MDPI, Basel, Switzerland. This article is an open access article distributed under the terms and conditions of the Creative Commons Attribution (CC BY) license (https:// creativecommons.org/licenses/by/ $4.0 /)$.

\begin{abstract}
Heterotopic ossification (HO) is one of the described phenomena after maxillofacial reconstructive surgery using fibular free flap (FFF) at the reception-site. The aim of this study was to determine the radiological incidence and form of $\mathrm{HO}$ along the fibular vascular pedicle as well as the rate of clinical symptoms if present. CT-scans of 102 patients who underwent jaw reconstructive surgery by using FFF from January 2005 to December 2019 were evaluated concerning the presence of HO. Subsequently, the patient files were evaluated to identify the cases with clinical signs and complications related to the presence of HO. A radiological classification of four different $\mathrm{HO}$ types was developed. Out of 102 patients, $29(28.43 \%)$ presented radiological findings of HO. Clinical symptoms were recorded in 10 cases $(9.8 \%)$ (dysphagia $(n=5)$, trismus $(n=3)$, bony masses $(n=2)$ ) and from these only five $(4.9 \%)$ needed surgical removal of calcified structures. HO occurs significantly in younger patients (mean 52.3 year). In maxillary reconstructions, $\mathrm{HO}$ was radiologically visible six months earlier than after mandibular reconstruction. Furthermore, HO is observed after every third maxilla and every fourth mandible reconstruction. This study developed for the first time a classification of four distinct $\mathrm{HO}$ patterns. HO types 1 and 2 were mostly observed after mandible reconstruction and type 4 predominantly after maxilla reconstruction.
\end{abstract}

Keywords: reconstructive surgery; microsurgery; fibular free flap; FFF; heterotopic ossification

\section{Introduction}

The fibular free flap (FFF) is the workhorse of defect-oriented reconstruction after combined hard and soft tissue resections within the maxillofacial region [1]. The graft was firstly introduced by Hidalgo et al. [2] and quickly considered as a safe and reliable osteo-fascio-cutaneous graft which is widely used worldwide. The available bone length is usually sufficient for reconstruction of the lower jaw up to class IV [3], offering the possibility of satisfactory oral rehabilitation using endosseous dental implants [4-6]. FFF provides a vascular pedicle of sufficient length for use in the entire head and neck region between forehead and clavicula [7] and shows an overall low donor site morbidity [8]. Furthermore, there is the option of forming one or more septo-cutaneous skin paddles, which are suitable for flap monitoring as well as for closing soft tissue defects of the head and neck region. Initially, a stable and sufficient vascular supply of the septo-cutaneous skin paddle was doubted [9], but as this graft became more widespread, knowledge of vascular supply via the perforator vessels of the septum intermusculare posterius and perforator vessels around the musculus soleus was improved [10-12].

There is still debate about the reconstruction time point, and whether it is best to perform reconstruction immediately or at a delayed time after the ablative oncological procedure. The necessity of cervical lymphadenectomy offers an ideal approach to suitable vessels for 
micro-anastomosis. Therefore the time of oncologic resection is the best time for reconstruction [13]. Another advantage is a decrease in surgical procedures and the opportunity for oral rehabilitation in less time [14]. Improved morphological assessment techniques such as frozen-section analysis and flat-panel volume computed tomography of the removed tissues allows an assessment regarding the complete resection of the tumor [15]. Such extended defects are often complex. Combined soft and hard tissue defects after surgery require free vascularized tissue transplant [16]. Wound healing at soft and hard tissue starts immediately after transfer of a combined osteo-fascio-cutaneous FFF. Fracture healing between the original jaw and fibular bone is a highly complex process. Several molecular interactions and gene regulatory processes are necessary for physiological bone growth. Bone healing and regeneration, as with wound healing of any other tissue, follow a sequential process with hematoma formation, tissue inflammation, and recruitment of stem cells. Finally, angiogenesis and bone remodeling will be initiated and continued [17]. Often described complications after reconstruction of maxillofacial structures are delayed wound healing and infection at both donor and receptor-site, (sub-)total flap loss [8,18], plate-related complications (infection, loosing of screw), plate exposure, and osseous non-union [19,20]. Additionally, function problems such as dysphagia, speech complaints, bulky skin paddle, reduced mouth opening, and scars were recorded [18]. Another reason for complaints and functional impairment at the reconstructed area is so-called heterotopic ossification (HO) [21,22].

$\mathrm{HO}$ is defined as mature lamellar bone tissue in extra-skeletal soft tissues [23]. Regardless of its genesis, $\mathrm{HO}$ has an endochondral structure, which lays on a cartilaginous matrix [24]. Concerning free flaps, $\mathrm{HO}$ of the vascular pedicle is described in the literature as a known complication of FFF [25-28]. Remarkably, evaluation of CT-scans shows frequencies up to $65 \%[22,29,30]$. In detail, there is a broad discrepancy between radiological presence and clinical symptoms of HO. Until now, no literature has been published on the role of virtual planning, necessary patient specific cutting guides for transplant shaping, or the onset of HO. Different theories of origin are discussed, considering the periosteal tissue of the vascular pedicle [26] as well as local mechanic factors and cytokine interactions as the keys role [31]. There is some evidence that FFF harvesting technique and remaining periosteum at the vascular pedicle play a relevant role in $\mathrm{HO}$ formation [21,32]. Interestingly $\mathrm{HO}$ is also reported in non-osseus transplants like fascio-cutaneous radial forearm free flaps and septomyo-cutaneous lateral upper arm flap, all without any contact to, or included, periosteum [33,34].

The aims of this study are:

1. to estimate the radiological and clinical form and frequency of $\mathrm{HO}$,

2. to define and compare different radio-morphological HO types introducing a new classification,

3. to report the surgical intervention rate for removing calcified structures,

4. and to investigate whether there is a correlation between: analog vs. digital planning, reconstruction methods (immediate vs. delayed), fibular segments and the occurrence of $\mathrm{HO}$.

\section{Material and Methods}

\subsection{Study Design and Patient Population}

The study was conducted as a monocentric, retrospective study. CT scans and cone beam CTs (CBCT) of patients who underwent successful FFF in the head and neck region from January 2005 to December 2019 were analyzed concerning the presence of heterotopic ossification (HO). The evaluated CT-scans were initiated either within the course of radiation planning or routine follow-up examination. CBCT were mostly performed to plan the insertion of dental implants for oral rehabilitation.

\subsection{Study Parameters and Evaluator Calibration}

The following parameters were collected: age at flap transfer, sex, primary diagnosis, planning procedure, location and type of defect, number of used fibula segments, extension of 
neck dissection, irradiation, clinical symptoms of $\mathrm{HO}$ and need for surgical intervention if $\mathrm{HO}$ was clinically symptomatic. All CT and CBCT-scans were analyzed independently for presence of $\mathrm{HO}$ by two authors (KS and $\mathrm{MK}$ ). If they disagreed, it was planned to take a third author's opinion (SB) in consideration, which was not necessary. MK and SB are experienced maxillofacial surgeons. KS is a fifth year dental medicine student.

\subsection{Inclusion and Exclusion Criteria for Study Subjects}

All patients who underwent a successful reconstruction of the maxilla or mandible (simultaneous or two-staged) with a FFF were enrolled in this study. Inclusion criteria were the presence of at least two CT-scans of the region of interest. Only CT-scans with a slice thickness $\leq 5 \mathrm{~mm}$ were included to ensure optimal $\mathrm{HO}$ detection. The minimum follow-up interval was four months. Cases with incomplete data sets, patient records, and those with less than two postoperative CT- or CBCT-scans of the head and neck region or a CT layer thickness $>5 \mathrm{~mm}$ were excluded.

\subsection{A New Classification of HO of the Vascular Pedicle and Periosseous Tissue Based on Radiological and Clinical Follow-Up}

Systematic evaluation of the patient records was performed to identify the cases in which the clinical presence of $\mathrm{HO}$ in the vascular pedicle region (palpable submandibular "bone-hard" swelling, ongoing difficulty swallowing and/or the periosteal tissue) led to clinical complications. For the radiological description, five types of HO patterns were defined (Figures 1 and 2): no recognizable ossification of the vascular pedicle or perosseous tissue corresponds to type 0 . Type 1 shows an ossification at the transition zone from fibula graft to vascular pedicle. Type 2 shows isolated ossification of the vascular pedicle without contact to the fibula. Type 3 is defined as an isolated $\mathrm{HO}$ of periosseous tissue without pedicle-associated ossification. Type 4 is a combination of $\mathrm{HO}$ of the vascular bundle and periosseous tissue.

\subsection{Statistical Analyses}

Chi-square-test was used to compare the frequency of $\mathrm{HO}$ in males and females. Students $t$-test was performed to compare the mean age at FFF-transfer between groups with and without radiological sign of $\mathrm{HO}$, after verification of normality. $p<0.05$ was defined as statistically significant. The statistical analysis (analogous to Kaplan-Meier survival function) was carried out with SPSS 25 (SPSS Inc., Chicago, IL, USA, http:/ / www.spss.com).

\subsection{Ethics Statement/Confirmation of Patients' Permission}

The study was approved by the local Ethics Committee of Justus-Liebig University Giessen (AZ34/20) and patients' permission/consent was not necessary in this retrospective study. The patients consented that their intraoral pictures and X-ray images could be used anonymously in the publication. In addition, all data in the Microsoft Excel spreadsheet were pseudonymized. 


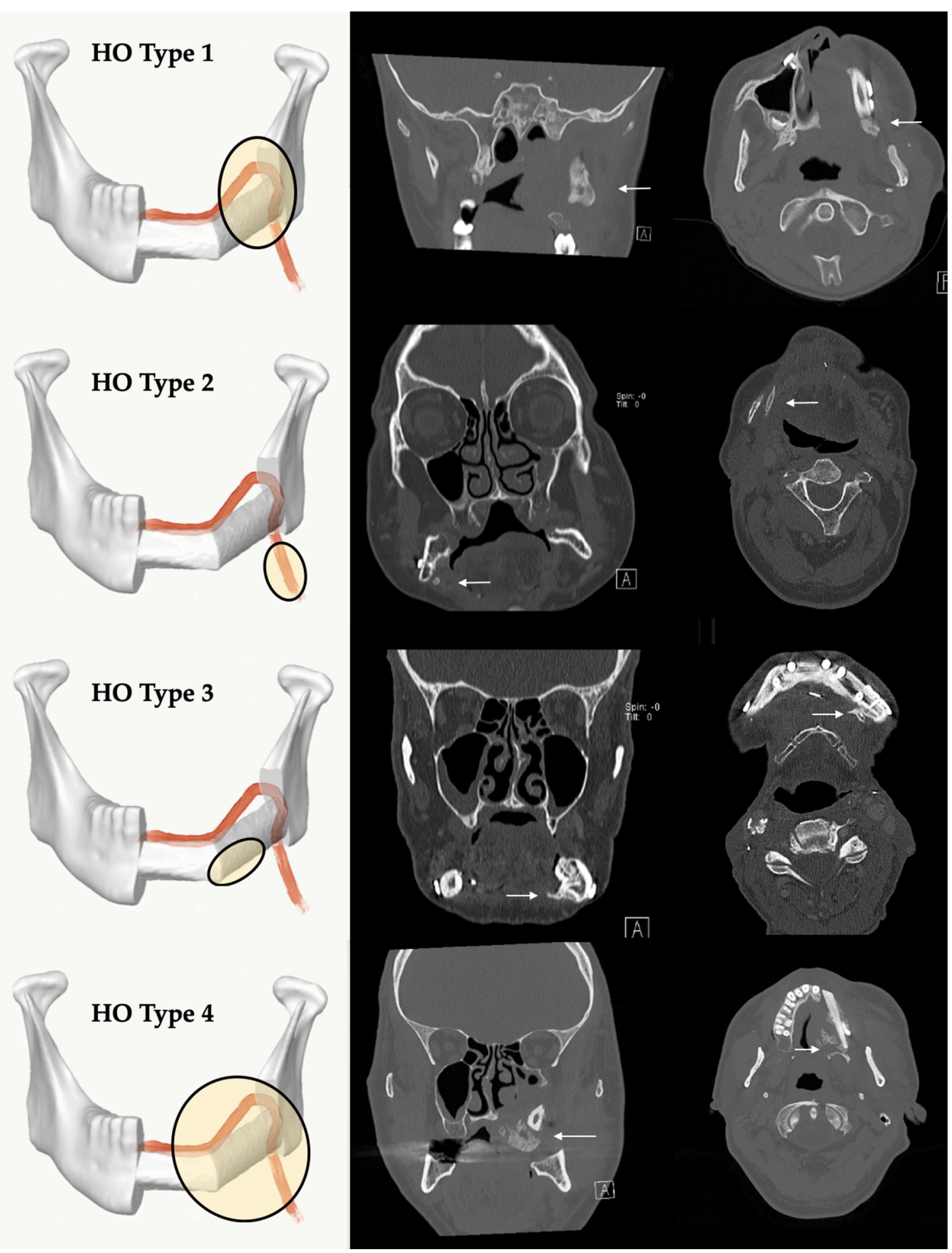

Figure 1. Classification of different radiological types of heterotopic ossification (HO): Type $1=\mathrm{HO}$ at the transition zone from fibula graft to vascular pedicle, Type $2=\mathrm{HO}$ isolated at the pedicle without contact to the fibula, Type $3=\mathrm{HO}$ appears isolated at the periosseous tissue without involvement of the vascular pedicle, Type $4=$ a combination with ossification of the pedicle and periosseous tissue. The white arrows mark region of interest. $\mathrm{A}=$ Anterior. 


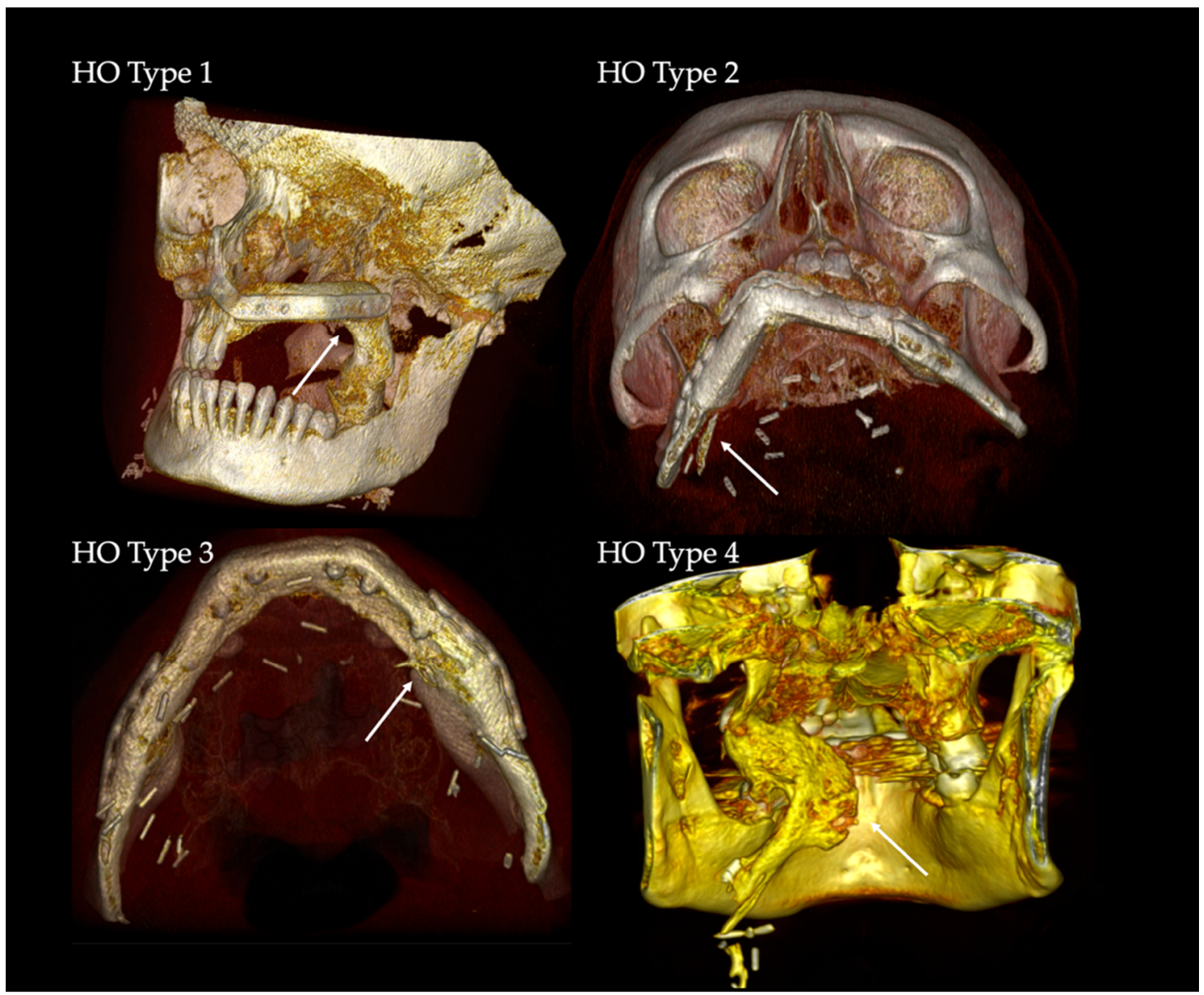

Figure 2. 3D-volume rendering of clinical examples of HO Types 1-4. The white arrows mark the regions of interest.

\section{Results}

A total of 149 cases fulfilled the defined inclusion and 47 cases matched the exclusion criteria. A total of 102 FFF cases (M: $n=66(64.7 \%), \mathrm{F}: n=36(35.3 \%))$ with complete data records during the period January 2005 to December 2019 were analyzed in the study (Table 1). The average age at surgery time in the HO- group was $58.69 \pm 11.92$ year (median 59.91 years, range 32.58-82.75 years) (follow-up $45.16 \pm 44.49$ months) and in the $\mathrm{HO}+$ group $52.30 \pm 14.39$ years (median 53.92 years, range $14.75-76.83$ years) (follow-up $66.59 \pm 45.04$ months). Both groups were tested for normal distribution. There was a significant age difference between the $\mathrm{HO}+$ and $\mathrm{HO}$ - group $(p=0.0236)$. FFF was used for maxillary reconstruction in 26 cases and for mandibular reconstruction in 76 cases.

Table 1. Clinical details of 102 patients after reconstruction of continuity defects of maxilla and mandible with fibular free flaps.

\begin{tabular}{|c|c|c|c|}
\hline$n=102$ & $\begin{array}{c}\text { HO- } \\
n=73(71.57 \%)\end{array}$ & $\begin{array}{c}\text { HO+ } \\
n=29(28.43 \%)\end{array}$ & \\
\hline Age (year), SD & $58.69 \pm 11.92$ & $52.30 \pm 14.39$ & $p=0.0236$ \\
\hline Follow-up (months), SD & $45.16 \pm 44.49$ & $66.59 \pm 45.04$ & \\
\hline HO duration until observation (months) & & $\begin{array}{c}\text { mean } 13.48 \\
\text { median } 9 \pm 16.54\end{array}$ & \\
\hline Surgical intervention & & 5 & \\
\hline Sex & & & \\
\hline Male & $41(40.20 \%)$ & $25(24.51 \%)$ & \\
\hline Female & $32(31.37 \%)$ & $4(3.92 \%)$ & $p=0.5096$ \\
\hline
\end{tabular}


Table 1. Cont.

\begin{tabular}{|c|c|c|c|}
\hline$n=102$ & $\begin{array}{c}\text { HO }- \\
n=73(71.57 \%)\end{array}$ & $\begin{array}{c}\text { HO+ } \\
n=29(28.43 \%)\end{array}$ & \\
\hline \multicolumn{4}{|c|}{ Preoperative planning/osteosynthesis } \\
\hline Analog/hand-bent & $45(44.12 \%)$ & $15(14.71 \%)$ & \\
\hline Virtual/custom-made & $28(27.45 \%)$ & $14(13.73 \%)$ & $p=0.3806$ \\
\hline \multicolumn{4}{|l|}{ Reconstruction } \\
\hline Immediately & $60(58.82 \%)$ & $19(18.63 \%)$ & \\
\hline Delayed & $13(12.75 \%)$ & $10(9.80 \%)$ & $p=0.1128$ \\
\hline \multicolumn{4}{|l|}{ Diagnosis } \\
\hline Malignant & $69(67.65 \%)$ & $22(21.57 \%)$ & \\
\hline Benign & $4(3.92 \%)$ & $4(3.92 \%)$ & \\
\hline Other (ORN, BPONJ, OM) & & $3(2.94 \%)$ & \\
\hline \multicolumn{4}{|l|}{ Location } \\
\hline Maxilla & $17(16.67 \%)$ & $9(8.82 \%)$ & \\
\hline Mandibula & $56(54.90 \%)$ & $20(19.61 \%)$ & $p=0.4553$ \\
\hline \multicolumn{4}{|c|}{ Maxilla defect type (Brown et Shaw 2010) [35] } \\
\hline II & $15(57.69 \%)$ & $8(30.77 \%)$ & \\
\hline III & $2(7.69 \%)$ & $1(3.85 \%)$ & \\
\hline \multicolumn{4}{|c|}{ Mandible defect type (Brown et al. 2016) [3] } \\
\hline $\mathrm{I}$ & $15(19.74 \%)$ & $7(9.21 \%)$ & \\
\hline Ic & $4(5.26 \%)$ & & \\
\hline II & $13(17.11 \%)$ & $3(3.95 \%)$ & \\
\hline IIC & $1(1.32 \%)$ & $1(1.32 \%)$ & \\
\hline III & $22(28.95 \%)$ & $7(9.21 \%)$ & \\
\hline IV & $1(1.32 \%)$ & $2(2.63 \%)$ & \\
\hline \multicolumn{4}{|l|}{ Reconstruction } \\
\hline Maxilla 1 FS & $14(53.85 \%)$ & $7(26.92 \%)$ & \\
\hline Maxilla 2 FS & $3(11.54 \%)$ & $2(7.69 \%)$ & \\
\hline Mandibula 1 FS & $24(31.58 \%)$ & $8(10.53 \%)$ & \\
\hline Mandibula 2 FS & $19(25.00 \%)$ & $6(7.89 \%)$ & \\
\hline Mandibula 3 FS & $13(17.11 \%)$ & $6(7.89 \%)$ & \\
\hline \multicolumn{4}{|l|}{ Neck dissection (ND) } \\
\hline None & $14(13.73 \%)$ & $12(11.76 \%)$ & \\
\hline Selective ND & $23(22.55 \%)$ & $4(3.92 \%)$ & \\
\hline MR ND & $36(35.29 \%)$ & $13(12.75 \%)$ & n.s. \\
\hline \multicolumn{4}{|l|}{ Neck surgery } \\
\hline One side & $54(52.94 \%)$ & $23(22.55 \%)$ & \\
\hline Both sides & $19(18.63 \%)$ & $6(5.66 \%)$ & $p=0.6213$ \\
\hline \multicolumn{4}{|l|}{ Postoperative irradiation } \\
\hline None & $31(30.39 \%)$ & $16(15.69 \%)$ & \\
\hline$<60 \mathrm{~Gy}$ & $20(19.61 \%)$ & $10(9.80 \%)$ & \\
\hline$\geq 60 \mathrm{~Gy}$ & $20(19.61 \%)$ & $2(1.96 \%)$ & \\
\hline Dosage unknown & $2(1.96 \%)$ & $1(0.98 \%)$ & n.s. \\
\hline
\end{tabular}

n.s. = not significant; ORN, Osteoradionecrosis; BPONJ, Bisphosphonate related osteonecrosis of the jaw; FS, number of used fibula segments; OM, Osteomyelitis; selective ND summarizes submandibular or supraomohyoidal neck dissection; MRND, modified radical ND.

Table S1 in the supplementary material depicts the collected data of our 29 patients with radiological $\mathrm{HO}(\mathrm{M}: n=25(86.2 \%), \mathrm{F}: n=4(13.8 \%))$. Extraosseous ossification occurred in $34.6 \%(n=9$ out of 26$)$ after maxillary and in $26.3 \%(n=20$ out of 76$)$ after mandibular reconstruction. The difference was not statistically significant $(p=0.4553)$.

The onset of $\mathrm{HO}$ in the CT-scan was drawn as incidence function (Kaplan Meier function), cumulative for reconstruction of maxilla and mandible with FFF (Figure 3). After an average time of 13.48 months (median 9.0 months), HO was observed in CT scans. Comparing time of detection of $\mathrm{HO}$ after maxillary (median $=5$ months, 95\% CI $=4.0-20.0$ months) and mandibular reconstruction, it is noticeable that maxillary $\mathrm{HO}$ occurred six months earlier than mandibular $\mathrm{HO}$ (median $=9.5$ months, 95\% CI = 5.0-13.0 months) (Figure 4). 
Incidence functions for reconstruction of continuity of mandible and maxilla were calculated separately (Figure 4).

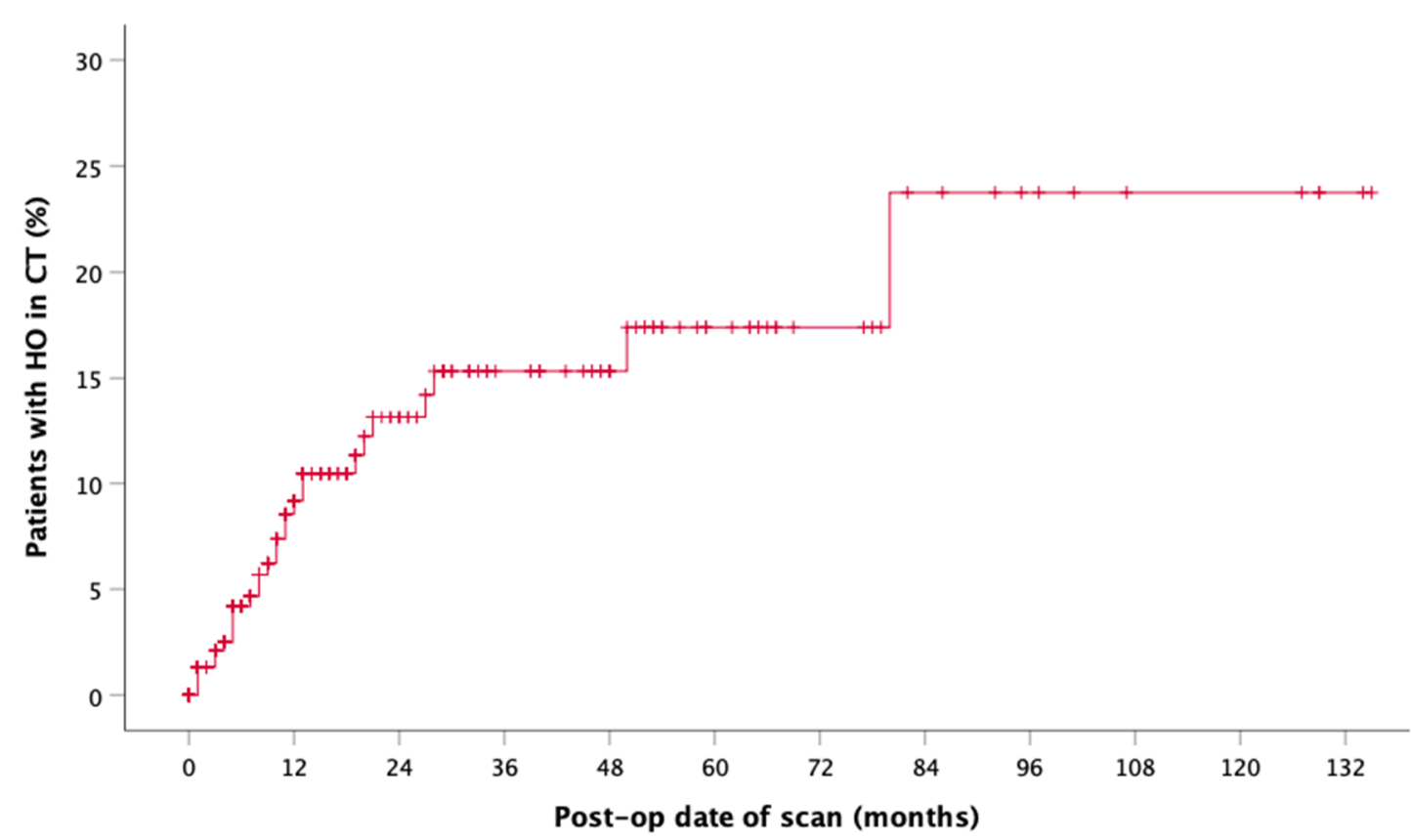

Figure 3. Incidence function shows the overall radiographic presence of $\mathrm{HO}$ aligned to the postoperative date of CT $(n=29)$.

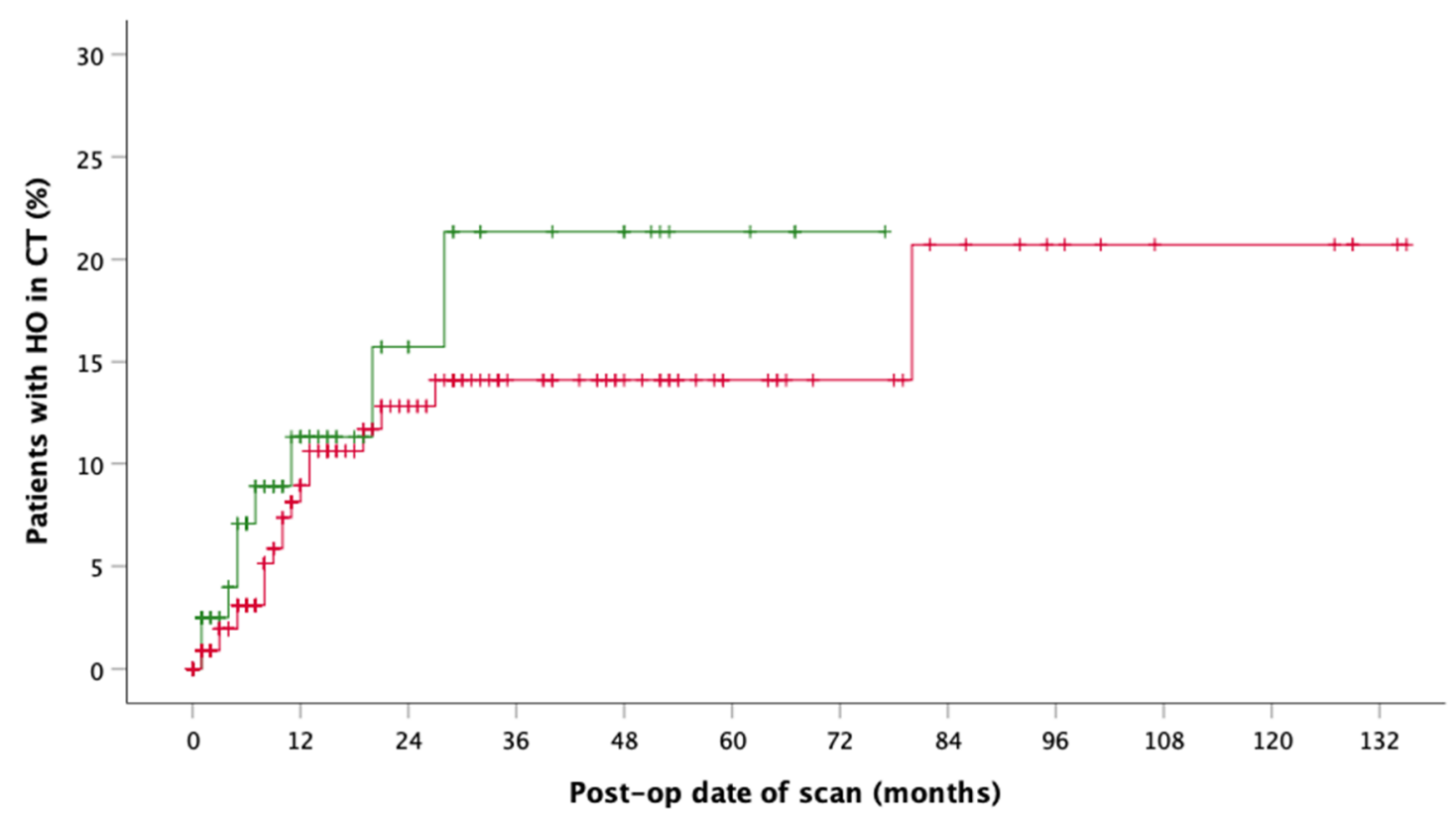

Figure 4. Incidence function shows the radiographic presence of $\mathrm{HO}$ by postoperative date of CT in maxillary (green, $n=9$ ) and mandible (red, $n=20$ ) reconstruction.

There were no statistically significant differences in the presence of radiological HO with regards to time of reconstruction $(p=0.1128)$ and the planning procedure, which was either analog (hand-bent, freehand osteotomized) or virtual (CAD/CAM plate, CAD/CAM cutting guides) $(p=0.3806)$. Jaw reconstruction was necessary in case of malignant disease in $89.22 \%$ of cases $(n=91)$ and 22 out of 91 developed HO. Reconstructions of continuity of the maxilla and mandible were classified by site and extent of the defect (Table 1). 
The extent of cervical lymphonodectomy (selective vs. modified radical neck dissection) and no lymphonodectomy showed no influence on the presence of $\mathrm{HO}$.

After adjuvant radiotherapy (RT) with $<60 \mathrm{~Gy}$, however, a near to similar incidence $(n=10$ out of $30(33.3 \%))$ was observed compared to no RT $(n=16$ of $47(34.0 \%))$. Within the subgroup of total irradiation dose of $\geq 60 \mathrm{~Gy}$, two cases of $\mathrm{HO}(n=2$ of $22(9.1 \%)$ ) were documented. These observations were not statistically significant.

The analysis of the CT-scans showed four different patterns (types) of HO. Distribution and results are shown in Table 2. HO Type 1 was most frequently observed in four cases after maxilla $(13.79 \%)$ and in 10 cases after mandible (34.48\%) reconstruction with FFF. Isolated ossification of the pedicle (Type 2) accounted for seven cases in the mandible $(24.14 \%)$ and $6.9 \%(n=2)$ in the maxilla. In three cases, combined ossification (Type 4$)$ after maxilla reconstruction (10.34\%) and only one case after mandibular reconstruction were recorded. HO Type 3 was only recorded in two cases after mandibular reconstruction $(6.9 \%)$. Figure 5 illustrates the distribution of HO types according to the number of fibula segments used. A homogeneous distribution of HO Type 1 is shown across all reconstruction localizations and shapes, while Type 2 and Type 4 are found in both types of jaw reconstruction. Type 3 could only be observed after mandibular reconstruction. Figure 6 outlines the appearance of $\mathrm{HO}$ in CT scans considering the number of used fibula segments in maxillary or mandible reconstruction. $\mathrm{HO}$ occurred more frequently after bi-segmental (33.3\%) maxillary reconstruction compared to mono-segmental (29.1\%) maxillary reconstruction. In the mandible, $\mathrm{HO}$ was most frequently observed after trisegmental $(26 \%)$ reconstruction compared to mono-segmental $(20 \%)$ and bi-segmental $(15 \%)$ reconstruction.

Table 2. HO was classified into four distinct radiological identifiable patterns. The distribution of HO types according to site of appearance (maxilla or mandible) and mean age (Minimum/Maximum), clinical impairments, and necessary surgical interventions are shown (Max., Maxilla; Mand., Mandible).

\begin{tabular}{|c|c|c|c|c|c|c|c|c|c|c|}
\hline \multirow[t]{2}{*}{ HO Type } & \multicolumn{2}{|c|}{ Maxilla } & \multicolumn{2}{|c|}{ Mandible } & \multicolumn{2}{|r|}{ Cumulative } & \multicolumn{2}{|c|}{ Complaints } & \multicolumn{2}{|c|}{ Surgery } \\
\hline & $n$ & $\begin{array}{l}\text { Age (Year) } \\
\text { (Min/Max) }\end{array}$ & $n$ & $\begin{array}{l}\text { Age (Year) } \\
\text { (Min/Max) }\end{array}$ & $n$ & Age (Year) \pm SD & Max. & Mand. & Max. & Mand. \\
\hline 0 & 17 & $\begin{array}{c}58.65 \\
(32.58 / 79.08)\end{array}$ & 56 & $\begin{array}{c}58.70 \\
(32.83 / 82.75)\end{array}$ & 73 & $58.69 \pm 11.92$ & & & & \\
\hline 1 & $\begin{array}{c}4 \\
(13.79 \%)\end{array}$ & $\begin{array}{c}47.63 \\
(14.75 / 68.25)\end{array}$ & $\begin{array}{c}10 \\
(34.48 \%)\end{array}$ & $\begin{array}{c}54.59 \\
(37.75 / 76.83)\end{array}$ & 14 & $52.60 \pm 15.85$ & 2 & 1 & 1 & - \\
\hline 2 & $\begin{array}{c}2 \\
(6.90 \%)\end{array}$ & $\begin{array}{c}63.5 \\
(53.92 / 73.08)\end{array}$ & $\begin{array}{c}7 \\
(24.14 \%)\end{array}$ & $\begin{array}{c}53.81 \\
(30.0 / 65.66)\end{array}$ & 9 & $55.96 \pm 13.61$ & 1 & 2 & 1 & - \\
\hline 3 & & & $\begin{array}{c}2 \\
(6.90 \%)\end{array}$ & $\begin{array}{c}51.21 \\
(46.08 / 56.33)\end{array}$ & 2 & $51.20 \pm 7.25$ & & 1 & & - \\
\hline 4 & $\begin{array}{c}3 \\
(10.34 \%)\end{array}$ & $\begin{array}{c}40.25 \\
(24.41 / 54.0)\end{array}$ & $\begin{array}{c}1 \\
(3.45 \%)\end{array}$ & 53.58 & 4 & $43.58 \pm 13.87$ & 3 & & 3 & - \\
\hline & $\begin{array}{c}9 \\
(31.03 \%)\end{array}$ & $\begin{array}{c}48.69 \\
(14.75 / 73.08)\end{array}$ & $\begin{array}{c}20 \\
(68.97 \%)\end{array}$ & $\begin{array}{c}53.92 \\
(30.0 / 76.83)\end{array}$ & 29 & $52.30 \pm 14.39$ & & & & \\
\hline
\end{tabular}

T-test showed a significant difference for the parameter 'age' and presence of $\mathrm{HO}$ $(p=0.0236)$ disregarding reconstructed upper or lower jaw. A statistical sub-analysis of the parameter 'age' concerning occurrence of HO in maxillary $(p=0.158)$ or mandible $(p=0.232)$ reconstruction revealed no statistically significant difference. 


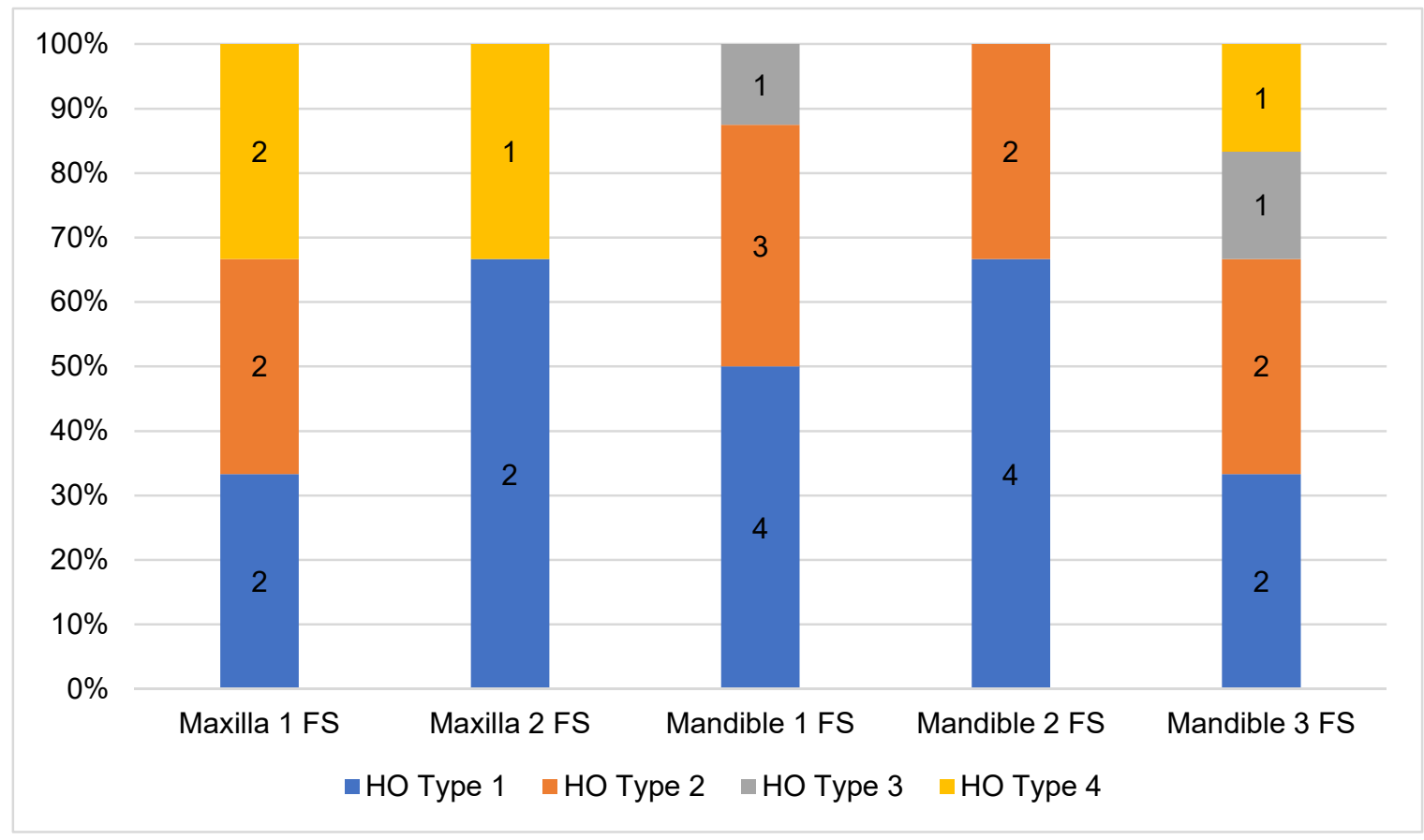

Figure 5. Distribution of HO types according to the number of used fibula segments for jaw reconstruction.

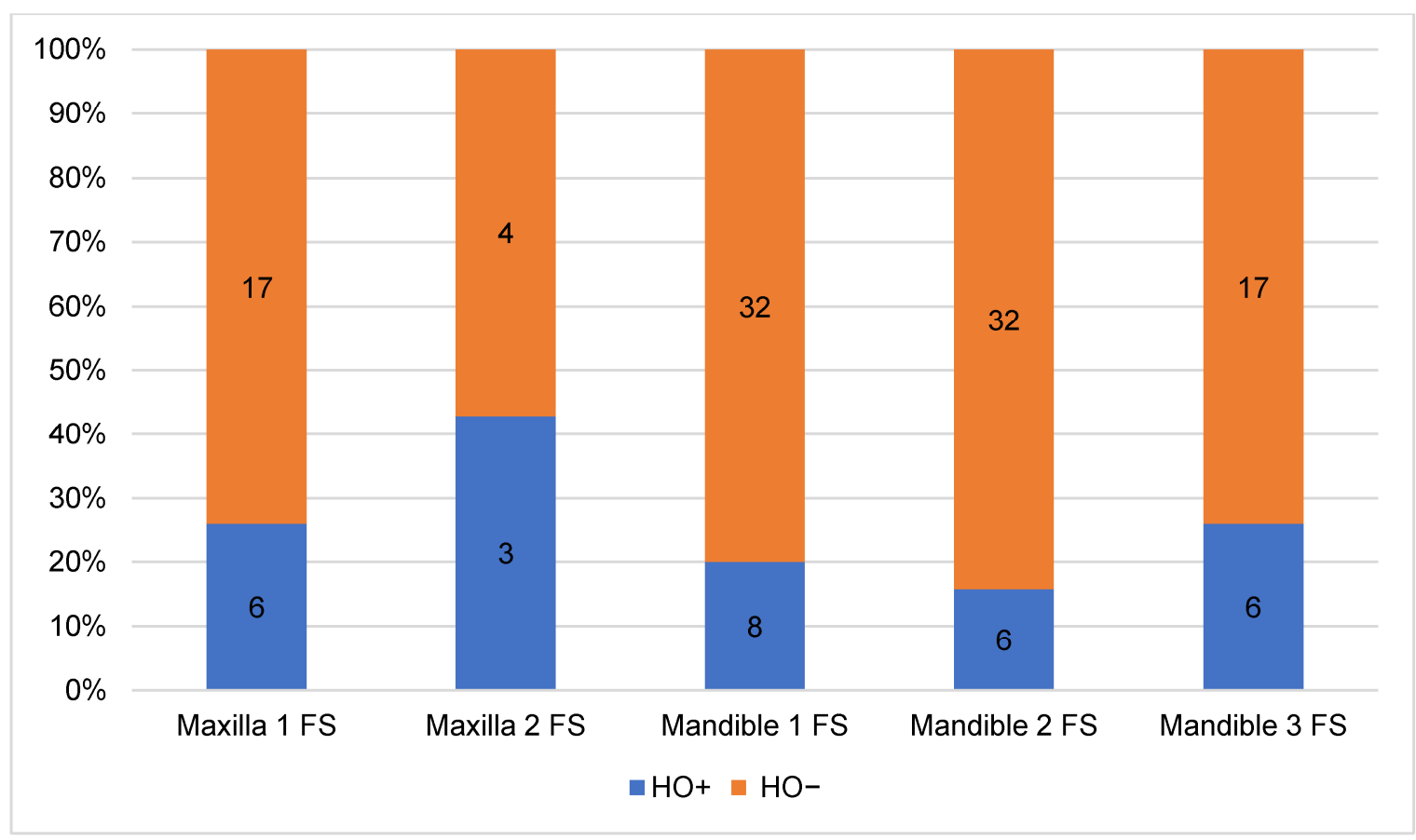

Figure 6. Relative proportion of $\mathrm{HO}$ in relation to localization and number of fibula segments (FS) used for jaw reconstruction.

The evaluated medical records of the $\mathrm{HO}+$ group showed clinical symptoms in 10 cases with swallowing difficulties $(n=5)$, trismus $(n=3)$, and palpable bony masses in level I $(n=2)$. Clinical complaints occurred after an average time of 6.3 months. Surgical intervention with a removal of calcification was only necessary in five cases. One of the patients (Figure 7) had a two-staged, virtually planned mono-segmental maxillary reconstruction after previous resection of a recurrence of a odontogenic kerato-cyst $(\mathrm{OKC})$. Early after flap transfer there was an extensive overgrowth of granulation tissue with subsequent periosteal ossification in the area of the palate and parts of the vascular pedicle (HO type 4). He suffered from 
severe dyspnea and dysphagia, prompting the surgical removal of the granulation tissue and parts of the heterotopic ossification. As a temporary wound closure, the defect was covered with a split skin graft and a screw-fixed dressing plate for five days. With further progress, a modelling osteotomy was performed simultaneously with the insertion of dental implants. Histopathologic evaluation of the tissue specimen confirmed the presence of mature bone tissue (Figure 7).


Figure 7. Images of an 54-year-old, healthy male who underwent subtotal hemi-maxillectomy due to a second recurrence of an odontogenic kerato-cyst (OKC). After more than one year later, we performed a virtually planned mono-segmental FFF transfer without a skin paddle for maxillary reconstruction (OPT 1). Three days after discharge, he consulted the emergency unit with progressive dyspnea and fear of asphyxiation in dorsal position. Clinical inspection showed large masses of soft and vulnerable granulation tissue (A). After carefully removing the tissue, we covered the bone with a split skin graft from the thigh (B). Six months later, we planned implantological rehabilitation. OPT and CBCT were accomplished and presented large bone masses at the palate (C, OPT 2). Clinical impression is shown on image (D). Prior to the insertion of four dental implants, we molded the FFF and removed bone masses (E). Implants were exposed four months later. Figure (F) shows the final prosthetic rehabilitation. 


\section{Discussion}

\subsection{HO after FFF in Literature}

Radiologically detected ossifications of the vascular pedicle of osteo-fascio-cutaneous FFF are described in the literature with a high incidence of up to $65 \%[22,29,30]$. Table 3 lists publications that reported the radiological and clinical incidences of $\mathrm{HO}$ after FFF. Individual case reports on the occurrence of $\mathrm{HO}$ after radialis flap [34], lateral upper arm flap [33], and scapula flap [36] have been published. HO rarely seems to lead to clinical symptoms and surgical correction is required even less frequently.

Table 3. Heterotopic ossification (HO): overview published cases.

\begin{tabular}{|c|c|c|c|c|}
\hline Authors & Flap $(n)$ & Incidence on Radiographs & Imaging & Clinical Symptoms/Surgical Removal \\
\hline Deschler et al., 1997 [37] & $\begin{array}{c}\text { FFF } \\
(n=38)\end{array}$ & No data available & OPT & $\begin{array}{c}8 \% \\
(n=3)\end{array}$ \\
\hline Smith et al., 2003 [27] & FFF, CR & & $\mathrm{CT}$ & $(n=1)$ \\
\hline Autelitano et al., 2008 [26] & $\operatorname{FFF}(n \sim 100)$ & No data available & & $\begin{array}{c}\sim 4 \% \\
(n=4)\end{array}$ \\
\hline Gonzales-Garcia et al., 2011 [25] & FFF, CR & & $\mathrm{CT}$ & $(n=1)$ \\
\hline Colletti et al., 2014 [38] & $\begin{array}{c}\text { FFF } \\
(n=92)\end{array}$ & No data available & & $\begin{array}{c}4.3 \% \\
(n=4)\end{array}$ \\
\hline Acarturk et al., 2011 [39] & FFF, CR & & $\mathrm{CT}$ & $(n=1)$ \\
\hline DeConde et al., 2011 [22] & $\begin{array}{c}\text { FFF } \\
(n=520) *\end{array}$ & $65 \%(n=43$ out of 66$)$ & $\mathrm{CT}$ & $\begin{array}{c}2.6 \% \\
(n=14 \text { out of } 520)\end{array}$ \\
\hline Myon et al., 2012 [36] & $\begin{array}{c}\text { FFF }(n=149) \\
\text { SF }(n=13)\end{array}$ & $\begin{array}{c}9.2 \%(n=15) \\
(n=14) \\
(n=1)\end{array}$ & OPT, CT & $\begin{array}{c}3.7 \% \\
(n=6)\end{array}$ \\
\hline Karagozoglu et al., 2013 [30] & $\begin{array}{c}\text { FFF } \\
(n=74)\end{array}$ & $27 \%(n=20)$ & OPT & No data \\
\hline Tarsitano et al., 2013 [21] & $\begin{array}{c}\text { FFF } \\
\operatorname{sp}(n=41) \\
\operatorname{mp}(n=20)\end{array}$ & $\begin{array}{c}17 \%(n=7) \\
0 \%\end{array}$ & OPT, CT & $\begin{array}{l}4.9 \% \\
(n=2)\end{array}$ \\
\hline Glastonbury et al., 2014 [29] & $\begin{array}{c}\text { FFF } \\
(n=32)\end{array}$ & $50 \%(n=16)$ & $\mathrm{CT}$ & $\begin{array}{l}3.13 \% \\
(n=1)\end{array}$ \\
\hline Baserga et al., 2016 [28] & $\begin{array}{c}\text { FFF } \\
(n=68)\end{array}$ & No data & & $\begin{array}{c}4.4 \% \\
(n=3)\end{array}$ \\
\hline This study & $\begin{array}{c}\text { FFF } \\
(n=102)\end{array}$ & $\begin{array}{l}28.4 \% \\
(n=29)\end{array}$ & $\mathrm{CT}, \mathrm{CBCT}$ & $\begin{array}{c}9.8 \%(n=10) / \\
4.9 \%(n=5)\end{array}$ \\
\hline
\end{tabular}

CR Case Report, FFF = fibular free flap, SF = scapula flap, $\mathrm{sp}=$ standard procedure, $\mathrm{mp}=$ modified supra-periosteal procedure,

* from 520 cases only 66 CT-scans were available for multiplanar reconstruction and analysis.

Different theories on the origin of $\mathrm{HO}$ are discussed. In osteo-fascio-cutaneous flaps, periosteal tissue near to the vascular pedicle seems to play a central role [26] as well as local mechanical factors and cytokine interactions [31]. The FFF harvesting technique with remaining periosteum on the vascular pedicle has significant influence on the development of $\mathrm{HO}$ [21,32]. All FFF in the investigation were harvested by the lateral approach [40] on the angled, perfused lower leg. In case of multi-segmental reconstructions, the corresponding preparation of the fibula was completed with the application of miter cuts (freestyle or prefabricated cutting guides) and osteosynthesis (hand-bent or custom-made). The proximal, free fibula segment was de-periosted, osteotomized and either discarded or used as a free graft (e.g., particulate). The exposed periosteum partially remains on the vascular pedicle, which is surrounded by a muscle layer. Preferred microvascular recipient vessels were the A. thyroidea superior or A. facialis. Direct end-to-end anastomosis of the external carotid artery was rarely used. While a long vascular pedicle facilitates microsurgicalvascular handling, it increases the risk of kinking pedicle. The longer vascular pedicle is prepared to a larger extent than the area with remaining adherent periosteum will be, from which $\mathrm{HO}$ can commence. Especially in young patients, careful periosteum-free 
vascular pedicle preparation should therefore be emphasized [39]. Tarsitano et al. could not observe any case of $\mathrm{HO}$ [36] by this modified harvesting technique $(n=20)$ with removal of the periosteum adhering to the vascular pedicle, which emphasizes a possible key role of osseo-inductive cells of the periosteum in the etiology of HO [21]. The periosteum is suspected to be a privileged target of recombinant human bone morphogenetic protein 2 [36]. Colletti et al. conclude that careful separation of the vascular pedicle from the periosteum seems to prevent $\mathrm{HO}$ [38]. An additional modification of this FFF harvesting procedure described by Kim et al. [32] suggests that, due to virtual planning, the extent of required fibula is exactly known and thus supra-periosteal proximal preparation can be performed after branching out of the fibular artery to the planned proximal osteotomy. They state that it is possible to omit one surgical step and thus shorten flap harvesting time [32]. Despite supra-periosteal dissection, there are cases in which pedicle ossification occurs [41]. The supra-periosteal dissection was not performed in the investigated group.

In addition to the outlined role of periosteal osteoprogenitor cells, other theories are discussed. The theory of fracture repair focuses on the presence of all cellular and molecular players such as bone morphogenetic protein (BMP), which are important for bone healing [42]. The ligands of the BMP signaling pathway, BMP-2 and BMP-4, have been known to induce bone formation for several decades [43,44]. Multiple studies have used this fact to recreate $\mathrm{HO}$ in vivo [45-47] or analyze the mechanistic basis of $\mathrm{HO}$ in vitro [48,49].

Blood flow and perfusion theory aims at changed pressure conditions in the arterial and venous system of the FFF after transfer of the arterial moderate and relative venous high pressure situation (valves, muscle pump) on the lower leg compared to the high arterial and low venous pressure situation of the head and neck region [36]. In addition, after microsurgical anastomosis of the vessels, there were changes in the flap perfusion. After flap dissection small arterial and venous collaterals were interrupted. Both factors, a higher arterial perfusion pressure at the cervical acceptor site and less opportunity of flap drainage to the surrounded tissue, can inflate the flap tissue. The mechanical theory describes the influence of physiological forces due to micro-stress on the callus and the bone healing of the attachment surfaces in the upper and lower jaw $[21,25,31,36]$.

\subsection{Classification of Four Different HO Patterns and Biological Etiology}

The HO classification suggested in this study distinguishes four types of HO. Type 1 is the most frequently observed variant across all reconstruction sites and forms. Concerning the referred theories of $\mathrm{HO}$ etiology, the bone healing/fracture repair theory describes the origin of $\mathrm{HO}$ from the resection site. Functional stress to the stabilized bone graft induces micromotion and enhances bone healing and callus growth [36]. We hypothesize that, as a result, the calcified tissue is a type of excessive bone healing that originates from the resection site and courses along the remaining periosteum at the pedicle by molecular stimulation from osteoprogenitor recruitment $[31,42,50]$.

Type 2 may be the result of isolated periosteal cells in contact with osteocytes along the pedicle from osteo-cutaneous FFF [26,51-53]. A long vascular pedicle with remaining periosteal cells therefore offers more potential for the development of $\mathrm{HO}$ [25]. We expected that HO Type 2 will be more common, especially in maxillary reconstructions but we found only two cases after maxilla, but seven cases after mandible reconstruction. However, molecular interactions and the influence of BMPs on the induction of wound healing could promote $\mathrm{HO}$ formation [31]. Local factors could have additional influence after bone resections.

HO Type 3 was only observed after mandible reconstruction. Its clinical appearance is similar to torus mandibularis. The occurrence of ectopic oral bone formation is probably the result of functional aspects of mastication [54,55]. Thus, this HO type could be triggered by manipulation of the periosteum and its dissection during preparation and maintained by functional factors induced by mastication. In addition, mechanical stress (tension) supports BMP signaling [31]. Keeping this in mind, we expected to find HO Type 3 occurring more frequently in poly-segmental reconstructions close to the resection sites 
and more particularly at intersegmental graft sites. There are discrepancies between cross sections of resection sites and FFF. Remnant free periosteum after poly-segmental shaping procedure around vascular bundle needs to be considered as an origin of $\mathrm{HO}$. There were no clear reasons why HO Type 3 was not found after maxillary reconstruction. One thinkable hypothesis is that HO Type 3 origin might be an hyperperfused and inflated bone feeder vessel via the above-mentioned mechanisms of blood flow and perfusion theory. For maxillary reconstruction the strong and rigid tissue of the gum might be a sufficient resistance to prevent its development in compare to the more loose and wide tissue of the floor of the mouth.

Changes in blood flow and pressure could also induce HO Type 4 [36]. Three cases after maxilla and one after mandible reconstruction can be assigned to HO Type 4 . This pattern was observed in younger patients (mean age $43.58 \mathrm{y}$ ). Focused on the morphological architecture of the surrounding soft tissue, the micro-vessels seem to be inflated. There is also an increase in bone and blood vessels during callus healing normally reported in stabilized fractures [56]. In the clinical case presented in Figure 7, we hypothesize that the overwhelming granulation of the soft tissue might be an early clinical expression of upcoming HO. Only in this case was no skin paddle used to cover the soft tissue of the graft which obviously led to granulation tissue. The low pressure from the surrounding functional soft tissue (tongue, floor of mouth, cheek) appears to be one possible cofactor in the development of HO. In maxilla reconstruction, a tunnel for the vascular pedicle has to be dissected bluntly. Following McCarthy's remarks, a superficial tunnel in the face-lift plane facilitates the course of vessels and, if the maxillary tubercle is resected, access can be gained by a parapharyngeal approach medial to the mandible [57]. Here, we also recognized HO (Figures 1, 2 and 7). In mandible reconstruction, HO Type 4 was not as distinctive as in maxilla reconstruction. It is conceivable that the neck tissue surrounding the vascular pedicle sufficiently counteracts the changed perfusion pressures after flap transfer. This could be a reason why pronounced changes such as in the tunnel area of the oral cavity after maxilla reconstruction could not be observed.

\subsection{Impact of Analogous and Virtual Planning}

In the literature, $\mathrm{HO}$ appears to occur more frequently in maxillary reconstructions $[27,36]$. $\mathrm{HO}$ was found in $34 \%$ ( $n=9$ of 26$)$ of all cases of maxillary reconstructions with FFF. This corresponds to a ratio of approximately 1:3. However, overall, more than two thirds of radiological observed $\mathrm{HO}$ cases $(69 \%, n=20)$ were recorded after mandibular reconstruction. At a total number of 76 successfully performed mandibular reconstructions, we identified 20 cases of HO. This corresponds to a ratio of about 1:4. Since 2015, we have been planning jaw reconstructions digitally. The results show a radiological incidence after analogous (11.45\%) and digitally $(10.69 \%)$ planning procedures. However, in the early years of jaw reconstruction, cases were planned analogously and were realized "manually" [58]. In recent years computer-assisted planning is clinical routine and, in addition to custom-made resection and cutting guides, patient-specific manufactured osteosynthesis plates are available [59-64]. The selection of the donor region and reconstruction morphology is the subject of current research into the use of algorithm-based automated procedures [65]. There was no significant difference in the presence of $\mathrm{HO}$ between virtually planned and CAD/CAM stabilized fibula $(10.69 \%)$ grafts than in those of analog and hand-bent osteosynthesis $(11.45 \%)$.

\subsection{Frequency of Clinical Symptoms and Surgical Removal of HO}

Although the ossification of the vascular pedicle according to radiological criteria seems to be common [29], clinical complications seems to be rare. Despite a radiological incidence of over $28.43 \%$, we identified 10 cases of clinically symptomatic HO $(9.8 \%)$ in the investigated collective with swallowing difficulties $(n=5)$, trismus $(n=3)$, and bony masses in level I $(n=2)$. Only five patients $(4.9 \%)$ needed a surgical intervention to remove calcification. On average, clinical complaints occurred after 4.4 months and surgical removal of calcified structures was performed after 12.6 months. $\mathrm{HO}$ and the planned 
removal of HO-related structures is a definite indication for surgery. In our opinion, changing the surgical harvesting procedure (supra-periosteal preparation of the proximal pedicle) does not seem to be advisable regarding the background of the low incidence of clinical symptomatic $\mathrm{HO}$ and the multifactorial genesis, where the periosteum plays an essential role.

However, excessive new bone formation in the entire graft area (HO Type 4) can result in massive clinical impairment [27]. Depending on graft location, the course of the vascular bundle and the region of anastomosis, the incidence of $\mathrm{HO}$ may be underestimated. According to the literature, $\mathrm{HO}$ is rarely symptomatic in a way that surgical intervention is indicated. However, removal of ectopic bone mass may be necessary in cases of impaired movement of mandibula, pain during mastication or disturbing submandibular masses in neck level I or II after exclusion of a recurrence of the proper oncological disease [21,36]. It is remarkable that all five surgically treated cases in the present investigation occurred after maxillary reconstruction, because of functional impairment (Table 2). In case of extensive periosseous $\mathrm{HO}$, modelling osteotomy for recontouring and application of a screw-fixed dressing plate may be considered as a therapeutic strategy. Ossification of the vascular pedicle at the transition from FFF to pedicle (Type 1) and isolated HO of the pedicle (Type 2) can be treated surgically if clinical symptoms are clear. Careful, subtle preparation of vascular stalk is only necessary during the early phase after transplantation until the graft is adequately perfused with blood. Myon et al. report that, in one case, the removal of a pedicle-associated HO did not lead to any reduction of the flap vitality [36]. Sufficient neovascularization to allow FFF survival independent of the vascular pedicle has been reported to occur within 4 to 12 weeks [66].

\subsection{Effect of Irradiation on HO Occurrence}

It is interesting to note that adjuvant irradiation (group $<60 \mathrm{~Gy}$ and $\geq 60 \mathrm{~Gy}$ ) leads to a decrease of the number of $\mathrm{HO}$ cases (not statistically significant). In orthopedic surgery, the hip is the most common site of HO development and treatment. Radiotherapy (RT) has been shown to be particularly effective in the hip, knee, and elbow area. In studies, uni-fractionated radiation application of $7 \mathrm{~Gy}$ was performed after elbow surgery and was associated with favorable functional and radiological result [67]. Another study of nine patients with clinically significant $\mathrm{HO}$ at the elbow reported a majority of clinical improvement after irradiation. In this study, 5 Gy in two fractions and 6-7 Gy in one fraction were applied. The mean follow-up was 7.7 months [68]. For prevention of HO after hip endo-prosthetics, prophylactic radiotherapy with $1 \times 7$ Gy immediately before or up to $24 \mathrm{~h}$ after surgery is recommended [69]. This leads to the question of the influence of fractionation at overall low doses of 7 to 16-17 Gy. In adjuvant radiotherapy in the head and neck region single applications between 1.8-2.2 Gy are normally used. In summary, there are four main differences in oncological adjuvant RT in head and neck: low single application dosage between 1.8-2.2 Gy per fraction, onset of RT up to four weeks after operation, overall cumulative irradiation dose (56-72 Gy), and amount of 33-34 fractions.

\subsection{Limitations of This Study}

The evaluation shows statistically significant differences concerning 'Age' and the occurrence of HO. However, subgroup analysis concerning maxillary or mandible reconstruction mean age was without any significant results. However, where there is a difference in mean of 10 years between the $\mathrm{HO}+$ and $\mathrm{HO}-$ groups in maxilla reconstructions, the number of cases is too small and the age distribution too broad to reach statistical significance.

Limitations of the presented study are the retrospective design and the lack of defined imaging time points, so that the mean or median first observation time of $\mathrm{HO}$ at 3.48 and 9.0 months appears late. Glastonbury et al. described typical imaging findings of $\mathrm{HO}$ in three cases only one month after FFF [29]. However, the incidence functions show that about half of the observed cases become visible in CT scan within the first 12 postoperative 
months. The second half only develop in the following six years. The reasons for this remain unclear. Bone or fracture healing is complete so that continuous remodeling processes could play a role. Our mixed patient collective was mostly formed of oncologic patients $(87.78 \%)$. Two third were male and one third female. About $86 \%$ of the radiologically detected $\mathrm{HO}$ cases were male patients which could be a selection bias. Therefore, the bias continued in the clinical $(\mathrm{M}=8, \mathrm{~F}=2)$ and in the surgically treated group $(\mathrm{M}=4, \mathrm{~F}=1)$.

Finally, further investigation and more data is necessary to validate this newly introduced classification. Any new classification in medicine should be verified by an independent cohort.

\section{Conclusions}

Extraosseous heterotopic ossification ( $\mathrm{HO})$ is a known phenomenon of osteo-cutaneous fibular free flap (FFF) after ablative tumor surgery and jaw reconstruction and can lead to clinical complications. Trismus, mastication pain and/or rough submandibular masses could be an indicator of $\mathrm{HO}$ if postoperative scars and tumor recurrence are excluded.

Radiologically, $\mathrm{HO}$ appears to occur more frequently in younger and male patients. No correlation between $\mathrm{HO}$ and the method of planning (analog vs. digital), the type of osteosynthesis (hand-bent vs. custom-made), or time of reconstruction (immediately vs. delayed) were found. A modified harvesting technique with a vascular pedicle without periosteal tissue seems to be an effective method to avoid heterotopic ossifications. This method could prevent the development of $\mathrm{HO}$ in maxillary reconstruction. In case of extensive $\mathrm{HO}$, the modelling osteotomy for jaw recontouring and the application of a screw-fixed dressing plate could be considered as a therapeutic strategy.

To our knowledge, this is the first study to describe a classification of four different radiological HO patterns. Further studies for the classification's validation are required.

Supplementary Materials: The following are available online at https:/ /www.mdpi.com/2077-038 3/10/1/109/s1, Table S1: Characteristics of HO+ cases $(n=29)$ after FFF.

Author Contributions: Conceptualization, M.K., S.A. and H.-P.H.; Data curation, M.K. and K.S.; Formal analysis, M.K., K.S., C.B. and S.A.; Investigation, M.K. and K.S.; Methodology, M.K.; Project administration, S.B.; Supervision, H.-P.H. and S.B.; Validation, M.K.; Visualization, M.K. and S.B.; Writing—original draft, M.K. and K.S.; Writing—review \& editing, C.B., S.A., H.-P.H. and S.B. All authors have read and agreed to the published version of the manuscript.

Funding: This research received no external funding.

Institutional Review Board Statement: The study was conducted according to the guidelines of the Declaration of Helsinki and approved by the Ethics Committee of Justus-Liebig University Giessen (AZ34/20).

Informed Consent Statement: Patients' permission/consent was not necessary in this retrospective study.

Data Availability Statement: The data presented in this study are available on request from the corresponding author.

Acknowledgments: The authors are grateful for the consent of the patient for presented X-rays and clinical images. This publication forms part of the dental doctoral thesis of the second author (KS).

Conflicts of Interest: The authors declare no conflict of interest.

\section{References}

1. Hayden, R.E.; Mullin, D.P.; Patel, A.K. Reconstruction of the segmental mandibular defect: Current state of the art. Curr. Opin. Otolaryngol. Head Neck Surg. 2012, 20, 231-236. [CrossRef]

2. Hidalgo, D.A. Fibula free flap: A new method of mandible reconstruction. Plast. Reconstr. Surg. 1989, 84, 71-79. [CrossRef]

3. Brown, J.S.; Barry, C.; Ho, M.; Shaw, R. A new classification for mandibular defects after oncological resection. Lancet Oncol. 2016, 17, e23-e30. [CrossRef]

4. Hakim, S.G.; Kimmerle, H.; Trenkle, T.; Sieg, P.; Jacobsen, H.C. Masticatory rehabilitation following upper and lower jaw reconstruction using vascularised free fibula flap and enossal implants-19 years of experience with a comprehensive concept. Clin. Oral Investig. 2015, 19, 525-534. [CrossRef] 
5. Attia, S.; Wiltfang, J.; Streckbein, P.; Wilbrand, J.F.; El Khassawna, T.; Mausbach, K.; Howaldt, H.P.; Schaaf, H. Functional and aesthetic treatment outcomes after immediate jaw reconstruction using a fibula flap and dental implants. J. Craniomaxillofac. Surg. 2019, 47, 786-791. [CrossRef]

6. Attia, S.; Wiltfang, J.; Pons-Kuhnemann, J.; Wilbrand, J.F.; Streckbein, P.; Kahling, C.; Howaldt, H.P.; Schaaf, H. Survival of dental implants placed in vascularised fibula free flaps after jaw reconstruction. J. Craniomaxillofac. Surg. 2018, 46, 1205-1210. [CrossRef]

7. Bluebond-Langner, R.; Rodriguez, E.D. Application of skeletal buttress analogy in composite facial reconstruction. Craniomaxillofac. Trauma Reconstr. 2009, 2, 19-25. [CrossRef]

8. Attia, S.; Diefenbach, J.; Schmermund, D.; Böttger, S.; Pons-Kühnemann, J.; Scheibelhut, C.; Heiss, C.; Howaldt, H.-P. Donor-Site Morbidity after Fibula Transplantation in Head and Neck Tumor Patients: A Split-Leg Retrospective Study with Focus on Leg Stability and Quality of Life. Cancers 2020, 12, 2217. [CrossRef]

9. Schusterman, M.A.; Reece, G.P.; Miller, M.J.; Harris, S. The osteocutaneous free fibula flap: Is the skin paddle reliable? Plast. Reconstr. Surg. 1992, 90, 787-793. [CrossRef]

10. Jones, N.F.; Monstrey, S.; Gambier, B.A. Reliability of the fibular osteocutaneous flap for mandibular reconstruction: Anatomical and surgical confirmation. Plast. Reconstr. Surg. 1996, 97, 707-716. [CrossRef]

11. Wong, C.H.; Tan, B.K.; Wei, F.C.; Song, C. Use of the soleus musculocutaneous perforator for skin paddle salvage of the fibula osteoseptocutaneous flap: Anatomical study and clinical confirmation. Plast. Reconstr. Surg. 2007, 120, 1576-1584. [CrossRef]

12. Winters, H.A.; de Jongh, G.J. Reliability of the proximal skin paddle of the osteocutaneous free fibula flap: A prospective clinical study. Plast. Reconstr. Surg. 1999, 103, 846-849. [CrossRef]

13. Schusterman, M.A.; Harris, S.W.; Raymond, A.K.; Goepfert, H. Immediate free flap mandibular reconstruction: Significance of adequate surgical margins. Head Neck 1993, 15, 204-207. [CrossRef] [PubMed]

14. Chana, J.S.; Chang, Y.M.; Wei, F.C.; Shen, Y.F.; Chan, C.P.; Lin, H.N.; Tsai, C.Y.; Jeng, S.F. Segmental mandibulectomy and immediate free fibula osteoseptocutaneous flap reconstruction with endosteal implants: An ideal treatment method for mandibular ameloblastoma. Plast. Reconstr. Surg. 2004, 113, 80-87. [CrossRef]

15. Schaaf, H.; Wahab-Gothe, T.; Kerkmann, H.; Streckbein, P.; Obert, M.; Pons-Kuehnemann, J.; Ahrens, M.; Howaldt, H.P.; Attia, S. Comparison between flat-panel volume computed tomography and histologic assessments of bone invasion of maxillofacial tumors: Utility of an instantaneous radiologic diagnostic tool. Oral Surg. Oral Med. Oral Pathol. Oral Radiol. 2017, 124, 191-198. [CrossRef]

16. Iizuka, T.; Hafliger, J.; Seto, I.; Rahal, A.; Mericske-Stern, R.; Smolka, K. Oral rehabilitation after mandibular reconstruction using an osteocutaneous fibula free flap with endosseous implants. Factors affecting the functional outcome in patients with oral cancer. Clin. Oral Implants Res. 2005, 16, 69-79. [CrossRef]

17. Marsell, R.; Einhorn, T.A. The biology of fracture healing. Injury 2011, 42, 551-555. [CrossRef]

18. Verhelst, P.J.; Dons, F.; Van Bever, P.J.; Schoenaers, J.; Nanhekhan, L.; Politis, C. Fibula Free Flap in Head and Neck Reconstruction: Identifying Risk Factors for Flap Failure and Analysis of Postoperative Complications in a Low Volume Setting. Craniomaxillofac. Trauma Reconstr. 2019, 12, 183-192. [CrossRef]

19. Zavattero, E.; Fasolis, M.; Garzino-Demo, P.; Berrone, S.; Ramieri, G.A. Evaluation of plate-related complications and efficacy in fibula free flap mandibular reconstruction. J. Craniofac. Surg. 2014, 25, 397-399. [CrossRef]

20. Rendenbach, C.; Steffen, C.; Hanken, H.; Schluermann, K.; Henningsen, A.; Beck-Broichsitter, B.; Kreutzer, K.; Heiland, M.; Precht, C. Complication rates and clinical outcomes of osseous free flaps: A retrospective comparison of CAD/CAM versus conventional fixation in 128 patients. Int. J. Oral Maxillofac. Surg. 2019, 48, 1156-1162. [CrossRef]

21. Tarsitano, A.; Sgarzani, R.; Betti, E.; Oranges, C.M.; Contedini, F.; Cipriani, R.; Marchetti, C. Vascular pedicle ossification of free fibular flap: Is it a rare phenomenon? Is it possible to avoid this risk? Acta Otorhinolaryngol. Ital. 2013, 33, 307-310. [PubMed]

22. DeConde, A.S.; Vira, D.; Blackwell, K.E.; Moriarty, J.M.; Sercarz, J.A.; Nabili, V. Neck mass due to pedicle ossification after oromandibular reconstruction. Laryngoscope 2011, 121, 2095-2099. [CrossRef] [PubMed]

23. Edwards, D.S.; Clasper, J.C. Heterotopic ossification: A systematic review. J. R. Army Med. Corps 2015, 161, 315-321. [CrossRef] [PubMed]

24. Dey, D.; Wheatley, B.M.; Cholok, D.; Agarwal, S.; Yu, P.B.; Levi, B.; Davis, T.A. The traumatic bone: Trauma-induced heterotopic ossification. Transl. Res. 2017, 186, 95-111. [CrossRef] [PubMed]

25. Gonzalez-Garcia, R.; Manzano, D.; Ruiz-Laza, L.; Moreno-Garcia, C.; Monje, F. The rare phenomenon of vascular pedicle ossification of free fibular flap in mandibular reconstruction. J. Craniomaxillofac. Surg. 2011, 39, 114-118. [CrossRef]

26. Autelitano, L.; Colletti, G.; Bazzacchi, R.; Biglioli, F. Ossification of vascular pedicle in fibular free flaps: A report of four cases. Int. J. Oral Maxillofac. Surg. 2008, 37, 669-671. [CrossRef]

27. Smith, R.B.; Funk, G.F. Severe trismus secondary to periosteal osteogenesis after fibula free flap maxillary reconstruction. Head Neck 2003, 25, 406-411. [CrossRef]

28. Baserga, C.; Massarelli, O.; Bolzoni, A.R.; Rossi, D.S.; Beltramini, G.A.; Baj, A.; Gianni, A.B. Fibula free flap pedicle ossification: Experience of two centres and a review of the literature. J. Craniomaxillofac. Surg. 2018, 46, 1674-1678. [CrossRef]

29. Glastonbury, C.M.; van Zante, A.; Knott, P.D. Ossification of the vascular pedicle in microsurgical fibular free flap reconstruction of the head and neck. AJNR Am. J. Neuroradiol. 2014, 35, 1965-1969. [CrossRef] 
30. Karagozoglu, K.H.; Winters, H.A.; Forouzanfar, T.; Schulten, E.A. Periosteal ossification of the vascular pedicle after reconstruction of continuity defects of the mandible and the maxilla with fibular free flaps: A retrospective study. Br. J. Oral Maxillofac. Surg. 2013, 51, 965-967. [CrossRef]

31. Yu, Y.Y.; Lieu, S.; Lu, C.; Colnot, C. Bone morphogenetic protein 2 stimulates endochondral ossification by regulating periosteal cell fate during bone repair. Bone 2010, 47, 65-73. [CrossRef] [PubMed]

32. Kim, B.B.; Kaleem, A.; Alzahrani, S.; Yeoh, M.; Zaid, W. Modified fibula free flap harvesting technique for prevention of heterotopic pedicle ossification. Head Neck 2019, 41, E104-E112. [CrossRef] [PubMed]

33. Jehn, P.; Zimmerer, R.; Dittmann, J.; Fedchenko, M.; Gellrich, N.C.; Spalthoff, S. Ossification of the Vascular Pedicle After Microsurgical Soft Tissue Transfer of the Lateral Upper Arm Free Flap. Ann. Plast. Surg. 2019, 83, e39-e42. [CrossRef] [PubMed]

34. Gangidi, S.R.; Courtney, D. "You reap what you sow"-A case of heterotopic ossification within a fasciocutaneous radial forearm free flap reconstruction. Int. J. Oral Maxillofac. Surg. 2013, 42, 458-459. [CrossRef] [PubMed]

35. Brown, J.S.; Shaw, R.J. Reconstruction of the maxilla and midface: Introducing a new classification. Lancet Oncol. 2010, 11, 1001-1008. [CrossRef]

36. Myon, L.; Ferri, J.; Genty, M.; Raoul, G. Consequences of bony free flap's pedicle calcification after jaw reconstruction. J. Craniofac. Surg. 2012, 23, 872-877. [CrossRef]

37. Deschler, D.G.; Hayden, R.E. Bone spur presenting as a submandibular mass following free fibula reconstruction of the mandible. Am. J. Otolaryngol. 1997, 18, 425-427. [CrossRef]

38. Colletti, G.; Autelitano, L.; Rabbiosi, D.; Biglioli, F.; Chiapasco, M.; Mandala, M.; Allevi, F. Technical refinements in mandibular reconstruction with free fibula flaps: Outcome-oriented retrospective review of 99 cases. Acta Otorhinolaryngol. Ital. 2014, 34, 342-348.

39. Acarturk, T.O.; Aslaner, E.E. Periosteal ossification from the vascular pedicle of a free fibular flap. J. Craniofac. Surg. 2011, 22, e29-e32. [CrossRef]

40. Gilbert, A. Vascularised transfer of the fibula shaft. Int. J. Microsurg. 1979, 1, 100.

41. Mays, A.C.; Gillenwater, A.M.; Garvey, P.B. Rare presentation of heterotopic ossification along a fibula free flap pedicle in a high-volume microvascular reconstruction practice. Head Neck 2018, 40, E21-E24. [CrossRef] [PubMed]

42. Kwong, F.N.; Harris, M.B. Recent developments in the biology of fracture repair. J. Am. Acad. Orthop. Surg. 2008, 16, 619-625. [CrossRef] [PubMed]

43. Urist, M.R.; Mikulski, A.; Lietze, A. Solubilized and insolubilized bone morphogenetic protein. Proc. Natl. Acad. Sci. USA 1979, 76, 1828-1832. [CrossRef] [PubMed]

44. Takagi, K.; Urist, M.R. The reaction of the dura to bone morphogenetic protein (BMP) in repair of skull defects. Ann. Surg. 1982, 196, 100-109. [CrossRef]

45. Lounev, V.Y.; Ramachandran, R.; Wosczyna, M.N.; Yamamoto, M.; Maidment, A.D.; Shore, E.M.; Glaser, D.L.; Goldhamer, D.J.; Kaplan, F.S. Identification of progenitor cells that contribute to heterotopic skeletogenesis. J. Bone Joint Surg. Am. 2009, 91, 652-663. [CrossRef]

46. Liu, X.; Kang, H.; Shahnazari, M.; Kim, H.; Wang, L.; Larm, O.; Adolfsson, L.; Nissenson, R.; Halloran, B. A novel mouse model of trauma induced heterotopic ossification. J. Orthop. Res. 2014, 32, 183-188. [CrossRef]

47. Uchibe, K.; Son, J.; Larmour, C.; Pacifici, M.; Enomoto-Iwamoto, M.; Iwamoto, M. Genetic and pharmacological inhibition of retinoic acid receptor gamma function promotes endochondral bone formation. J. Orthop. Res. 2017, 35, 1096-1105. [CrossRef]

48. Tian, X.B.; Sun, L.; Yang, S.H.; Fu, R.Y.; Wang, L.; Lu, T.S.; Zhang, Y.K.; Fu, D.H. Ectopic osteogenesis of mouse bone marrow stromal cells transfected with BMP 2/VEGF(165) genes in vivo. Orthop. Surg. 2009, 1, 322-325. [CrossRef]

49. Peterson, J.R.; De La Rosa, S.; Sun, H.; Eboda, O.; Cilwa, K.E.; Donneys, A.; Morris, M.; Buchman, S.R.; Cederna, P.S.; Krebsbach, P.H.; et al. Burn injury enhances bone formation in heterotopic ossification model. Ann. Surg. 2014, 259, 993-998. [CrossRef]

50. Shirley, D.; Marsh, D.; Jordan, G.; McQuaid, S.; Li, G. Systemic recruitment of osteoblastic cells in fracture healing. J. Orthop. Res. 2005, 23, 1013-1021. [CrossRef]

51. Burstein, F.D.; Canalis, R.F. Studies on the osteogenic potential of vascularized periosteum: Behavior of periosteal flaps transferred onto soft tissues. Otolaryngol. Head Neck Surg. 1985, 93, 731-735. [CrossRef] [PubMed]

52. Ortak, T.; Ozdemir, R.; Uysal, A.; Ulusoy, M.G.; Sungur, N.; Sahin, B.; Kocer, U.; Sensoz, O. Osteogenic capacities of periost grafts, periost flaps and prefabricated periosteal flaps: Experimental study. J. Craniofac. Surg. 2005, 16, 594-600. [CrossRef] [PubMed]

53. Takato, T.; Harii, K.; Nakatsuka, T.; Ueda, K.; Ootake, T. Vascularized periosteal grafts: An experimental study using two different forms of tibial periosteum in rabbits. Plast. Reconstr. Surg. 1986, 78, 489-497. [CrossRef] [PubMed]

54. Cortes, A.R.; Jin, Z.; Morrison, M.D.; Arita, E.S.; Song, J.; Tamimi, F. Mandibular tori are associated with mechanical stress and mandibular shape. J. Oral Maxillofac. Surg. 2014, 72, 2115-2125. [CrossRef] [PubMed]

55. Morrison, M.D.; Tamimi, F. Oral tori are associated with local mechanical and systemic factors: A case-control study. J. Oral Maxillofac. Surg. 2013, 71, 14-22. [CrossRef] [PubMed]

56. Claes, L.; Eckert-Hubner, K.; Augat, P. The effect of mechanical stability on local vascularization and tissue differentiation in callus healing. J. Orthop. Res. 2002, 20, 1099-1105. [CrossRef]

57. McCarthy, C.M.; Cordeiro, P.G. Microvascular reconstruction of oncologic defects of the midface. Plast. Reconstr. Surg. 2010, 126, 1947-1959. [CrossRef]

58. Pellini, R.; Mercante, G.; Spriano, G. Step-by-step mandibular reconstruction with free fibula flap modelling. Acta Otorhinolaryngol. Ital. 2012, 32, 405-409. 
59. Wilde, F.; Cornelius, C.P.; Schramm, A. Computer-Assisted Mandibular Reconstruction using a Patient-Specific Reconstruction Plate Fabricated with Computer-Aided Design and Manufacturing Techniques. Craniomaxillofac. Trauma Reconstr. 2014, 7, 158-166. [CrossRef]

60. Cornelius, C.P.; Smolka, W.; Giessler, G.A.; Wilde, F.; Probst, F.A. Patient-specific reconstruction plates are the missing link in computer-assisted mandibular reconstruction: A showcase for technical description. J. Craniomaxillofac. Surg. 2015, 43, 624-629. [CrossRef]

61. Wilde, F.; Hanken, H.; Probst, F.; Schramm, A.; Heiland, M.; Cornelius, C.P. Multicenter study on the use of patient-specific CAD/CAM reconstruction plates for mandibular reconstruction. Int. J. Comput. Assist. Radiol. Surg. 2015, 10, 2035-2051. [CrossRef] [PubMed]

62. Liu, X.J.; Gui, L.; Mao, C.; Peng, X.; Yu, G.Y. Applying computer techniques in maxillofacial reconstruction using a fibula flap: A messenger and an evaluation method. J. Craniofac. Surg. 2009, 20, 372-377. [CrossRef] [PubMed]

63. Modabber, A.; Ayoub, N.; Mohlhenrich, S.C.; Goloborodko, E.; Sonmez, T.T.; Ghassemi, M.; Loberg, C.; Lethaus, B.; Ghassemi, A.; Holzle, F. The accuracy of computer-assisted primary mandibular reconstruction with vascularized bone flaps: Iliac crest bone flap versus osteomyocutaneous fibula flap. Med. Devices 2014, 7, 211-217. [CrossRef] [PubMed]

64. Wilde, F.; Winter, K.; Kletsch, K.; Lorenz, K.; Schramm, A. Mandible reconstruction using patient-specific pre-bent reconstruction plates: Comparison of standard and transfer key methods. Int. J. Comput. Assist. Radiol. Surg. 2015, 10, 129-140. [CrossRef]

65. Raith, S.; Rauen, A.; Mohlhenrich, S.C.; Ayoub, N.; Peters, F.; Steiner, T.; Holzle, F.; Modabber, A. Introduction of an algorithm for planning of autologous fibular transfer in mandibular reconstruction based on individual bone curvatures. Int. J. Med. Robot. 2018, 14. [CrossRef]

66. Mucke, T.; Wolff, K.D.; Rau, A.; Kehl, V.; Mitchell, D.A.; Steiner, T. Autonomization of free flaps in the oral cavity: A prospective clinical study. Microsurgery 2012, 32, 201-206. [CrossRef]

67. Robinson, C.G.; Polster, J.M.; Reddy, C.A.; Lyons, J.A.; Evans, P.J.; Lawton, J.N.; Graham, T.J.; Suh, J.H. Postoperative singlefraction radiation for prevention of heterotopic ossification of the elbow. Int. J. Radiat. Oncol. Biol. Phys. 2010, 77, 1493-1499. [CrossRef]

68. Heyd, R.; Strassmann, G.; Schopohl, B.; Zamboglou, N. Radiation therapy for the prevention of heterotopic ossification at the elbow. J. Bone Joint Surg. Br. 2001, 83, 332-334. [CrossRef]

69. Seegenschmiedt, M.H.; Makoski, H.B.; Micke, O.; the German Cooperative Group on Radiotherapy for Benign Diseases. Radiation prophylaxis for heterotopic ossification about the hip joint-A multicenter study. Int. J. Radiat. Oncol. Biol. Phys. 2001, 51, 756-765. [CrossRef] 